\title{
CARTAS DE JUAN DE MATA SEVILLANO, DUQUE DE SEVILLANO A RAMÓN MARÍA NARVÁEZ, DUQUE DE VALENCIA (1848-1864)
}

\author{
Letters from Juan de Mata Sevillano, Duque de Sevillano to \\ Ramón María Narváez, Duque de Valencia (1848-|864)
}

\author{
Agustín Fernández Escudero \\ Universidad Complutense de Madrid \\ affescudero@gmail.com
}

Cómo citar este artículo/Citation:

Agustín FERNÁNDEZ ESCUDERO, "Cartas de Juan de Mata Sevillano, duque de Sevillano a Ramón María Narváez, duque de Valencia (1848-18649", Hispania Nova, 18 (2020), págs. I a 37,

DOI: https://doi.org//0.203/8/hn.2020.5098
Copyright: () HISPANIA NOVA es una revista debidamente registrada, con ISSN II38-73I9 y Depósito Legal M 9472-1998. Los textos publicados en esta revista están -si no se indica lo contrario- bajo una licencia Reconocimiento-Sin obras derivadas 3.0 España de Creative Commons. Puede copiarlos, distribuirlos y comunicarlos públicamente siempre que cite su autor y la revista y la institución que los publica y no haga con ellos obras derivadas. La licencia completa se puede consultar en: http://creativecommons.org/licenses/by-nd/3.0/es/deed.es

\begin{abstract}
Resumen: El general Narváez, además de sus múltiples éxitos militares y políticos, puso cuidado en invertir su dinero diversificando el riesgo e incrementando las ganancias, según le asesoraba su banquero y compañero de partido, el duque de Sevillano. Dinero que, además de por esa idea de diversificar y por sus viajes y estancias en distintos países europeos, también tenía depositado en importantes casas financieras de París o Londres.

En la asidua correspondencia que mantuvieron estas dos personalidades, desde 1848 hasta 1864 , al menos en la del duque de Sevillano (la del Espadón de Loja dirigida al banquero no se ha conservado), se ha podido comprobar que, además de escribir sobre asuntos financieros, también lo hacían con causas meramente domésticas, pero que, Sevillano, a modo de corresponsal, también dedicaba muchos renglones de sus cartas para comunicar a su general, cuando este estaba ausente de Madrid, los pormenores de la política española.
\end{abstract}

Palabras clave: Sevillano, Narváez, correspondencia, comercial, doméstica, política.

\begin{abstract}
General Narváez, besides his numerous military and political successes, took great care in investing his money diversifying the associated risk and increasing profits, as advised by his banker and fellow party member, the duque de Sevillano. The general's money was deposited in important financial houses in Paris or London, due to the idea of diversifying and his trips to different European countries.

In the frequent correspondence that these two personalities held, from 1848 to 1864 , at least from the duque de Sevillano (the Espadón de Loja one addressed to the banker has not been kept), it has been proved that besides writing about financial matters, they also wrote about merely domestic matters; nonetheless, as a correspondent, Sevillano also dedicated many lines of his letters to communicate to his general, when he was absent from Madrid, the details of Spanish politics
\end{abstract}

Keywords: Sevillano, Narváez, correspondence, commercial, domestic, politics. 


\section{INTRODUCCIÓN}

Una vez localizados los cientos de cartas conservadas en la Real Academia de la Historia que Juan de Mata Sevillano, marqués de Fuentes de Duero y desde 1854, duque de Sevillano (Vicálvaro 1790-Madrid 1864), le dirigió, desde 1848 hasta su muerte en 1864, al general Ramón María Narváez y Campos, I duque de Valencia (Loja 1799-Madrid 1868), no se podía dejar de hacer un resumen de todas ellas, con el fin de entresacar, desde su contenido, la relación que existió entre estas dos personalidades ${ }^{1}$.

Es preciso indicar, antes de continuar, que tan solo se podrán citar las cartas que Sevillano le enviaba a Narváez, en algunos momentos casi a diario, pero no las contestaciones de este último, que, aunque en ocasiones se pueden deducir por las respuestas del banquero, los escritos del general, a pesar de las búsquedas realizadas, no se han localizado. Asimismo, tampoco se han conservado las copias de los escritos que, de forma oficial, debió guardar la casa Sevillano, o de forma particular, el propio marqués y duque. La misma suerte negativa se ha producido al intentar localizar cualquier otro documento perteneciente a Juan Sevillano y su banca, que hubiera recibido de otro amigo particular o cliente de la banca de la casa Sevillano, o viceversa ${ }^{2}$.

En un principio, el contacto epistolar que se produjo entre Juan de Mata Sevillano y Ramón María Narváez, cuando este estaba ausente de la Corte, se inició

\footnotetext{
${ }^{1}$ En el trabajo de Manuel SALCEDO OLID: Ramón María Narváez (1799-1868), Homo Legens, 2012, se citan algunas de estas cartas. Las relacionadas con puntuales asuntos familiares y otros concernientes a la política del partido moderado. PABÓN Y SUÁREZ DE URBINA: Narváez y su época, Espasa-Calpe, Madrid, 1983, p 74, dice que, una vez inventariados los documentos conservados por este militar, son, en números redondos, unos 16.500. Añadiendo su alabanza al político que guarda sus papeles para la historia, hecho poco frecuente en España, pero es una forma de demostrar que cuidaba sus fondos documentales para poder investigar y reconstruir su presente cuando fuera pasado.

${ }^{2}$ Valentín GONZÁLEZ, es el presidente de la Asociación de Investigación Histórica de Vicálvaro Vicus Albus, archivo donde se conserva la mayor parte de los documentos relacionados con la historia de esta villa, comenta que desconoce dónde pueden estar estos documentos, y que esta desaparición podría ser motivada por el fin en el que ha ido cayendo el ducado de Sevillano.
} 
como debía ser el normal entre un banquero y su cliente. Desde un «muy señor mío», que pronto pasó al «muy señor mío y dueño», y conforme iban aumentando los mutuos escritos llegar a «mi querido amigo» o «mi muy apreciable amigo». Y además de escribir sobre temas meramente comerciales de compraventa de fondos y letras, cuentas corrientes y cotizaciones, inversiones diversificadas en distintos campos, riesgos y aumento de ganancias; pasar a ser una crónica política desde Madrid, mezclada con los acontecimientos y una narración que, entre amigos deseosos de abrazarse, se preguntaban por sus viajes y sus dolencias, por sus familias y por distintos problemas domésticos.

Para un mejor seguimiento de las múltiples cartas que, escritas entre los años 1848 y 1864, Sevillano le dirigió a Narváez, se ha considerado oportuno agruparlas por años, y cuando lo requiera su contenido, en los tres apartados de: economía, política y familiar-particular. No obstante, en este trabajo se irá haciendo más hincapié, dependiendo del momento, en las inquietudes económicas del Espadón de Loja como cliente del banquero vicalvareño; en los sucesos políticos en los que, de forma directa o indirecta, se veían involucrados los dos personajes; o narrando los pormenores particulares de ellos, sus viajes o su vida familiar, con sus bodas, bautizos o fallecimientos. Estos últimos sucesos, con el fin de no hacer excesivamente extenso este artículo, algunas veces, se citarán someramente. No obstante, todos estos asuntos, e incluso alguno más que, por su reiteración o por su falta de relevancia, ni siquiera se mencionarán, se pueden ampliar en esta correspondencia ${ }^{3}$. Además, en

\footnotetext{
${ }^{3}$ Todos estos escritos, de los que no se citará a pie de página la referencia en cada caso por estar las fechas intercaladas, se encuentran en la Real Academia de la Historia divididos en dos grupos:

Uno - Archivo Narváez II. Narváez, Ramón María, duque de Valencia (1800-1868) Legajos 9/8130 (691520, fondo catálogo Fundación Sergio Fernández Larraín. Título «Cartas y documentos del duque de Sevillano al duque de Valencia. Recibos de testamentaría. 21 julio 1851/12 noviembre 1862». Dice que consta de 63 documentos. Los legajos figuran con estos títulos:
}

-Año 1862. Correspondencia con el Sr. Duque de Sevillano en la que constan las cantidades que me adelanto en dicho año y el pago que de todas ellas le hice resultando no deberle nada el día 15 de enero de 1863.

-Año 1864. Sevillano. Finiquitadas las cuentas que yo tenía con dicho Señor, según consta en el recibo de las herederas y en el libro de este año. Concluido.

-Año 1864, duque de Sevillano. Finiquitos de las cuentas corrientes que tenía el señor duque de Valencia con el de Sevillano y con las testamentarias y heredero de este señor.

-Año 1866. Recibos caducados referentes á la testamentaría de Sevillano que conservo para memoria. 
distintos momentos se reforzarán algunos de los comentarios escritos con aportaciones de archivos, noticias publicadas en la prensa y otros datos recogidos en la bibliografía publicada.

Se ha podido comprobar que en los años cincuenta y sesenta los contactos epistolares entre estos dos amigos eran tan fluidos como que llegaron a enviarse, mutuamente, cartas casi a diario. Hecho que se corrobora porque en uno de los escritos del año 1854, Sevillano le dijo a Narváez que se extrañaba de llevar tres días sin recibir carta suya. En otro momento, a los pocos meses, le escribía para decirle que precisamente no tenía nada que contarle, pero que jamás dejaría de escribirle.

\section{LOS PRIMEROS ESCRITOS. AÑOS 1846-1850}

Muchos de los títulos nobiliarios que los distintos reyes españoles fueron concediendo a lo largo de los últimos siglos en nuestro país, tuvieron su origen en los favores militares, en los logros políticos o en las ayudas económicas que los futuros nobles habían hecho a los monarcas de cada momento. En el siglo XIX existió una estrecha relación entre la gestión de lo público y lo privado que propiciaba el establecimiento de redes entre el mundo de la economía y el de la política, por lo que era sencillo encontrar personajes singulares que llegaron a alcanzar la gloria de ascender desde sus posiciones burguesas hasta la ansiada nobleza ${ }^{4}$. De hecho, según afirma Jesús Cruz, la sociedad española posterior a 1812 ofreció más oportunidades para el ascenso social ${ }^{5}$.

Dos -Archivo Narváez. Catálogo creado por Jesús Pabón en 1966-1967, con los números de legajos 9/7809-7875 con estos títulos, y un total de 526 documentos:

-Número 4, Sevillano, D. Juan. 1848-1851. Índice General y 112 documentos (Economía-PolíticaParticular).

-Número 5), Sevillano, D. Juan, 1852, 115 documentos.

II-F-b, Sevillano, D. Juan. 1853-1854, 176 documentos.

-Número 7, con 123 documentos, años 1855 -1865 y sin fecha..

${ }^{4}$ Agustín FERNÁNDEZ ESCUDERO: El Negocio de la Política. Biografía del duque de Sevillano (Vicálvaro 1790-Madrid 1864), La Ergástula, Madrid, 2013, p. 11.

${ }^{5}$ Jesús CRUZ: Los Notables de Madrid. Las bases sociales de la revolución liberal española, Alianza Editorial, Madrid, 2000, p. 166. Este autor ofrece un amplísimo estudio de distintos nuevos nobles surgidos en el siglo XIX, en el que no figura el duque de Sevillano, detallando sus procedencias, sus fortunas y sus posicionamientos sociales. 
En relación con el futuro duque de Sevillano, desde 1820 y durante más de veinte años, fue proveedor de paja y cebada a las caballerizas reales, que, por su desahogada situación económica, llegó a condonar en más de una ocasión sus suministros ${ }^{6}$. En consecuencia, el 11 de noviembre de 1846, Isabel II le concedió el título de vizconde de Sevillano ${ }^{7}$. Por tanto, Juan de Mata Sevillano y Fraile, como título de Castilla, fue nombrado senador vitalicio del reino por Real Decreto del 9 de diciembre ${ }^{8}$. Este cargo lo mantuvo hasta su fallecimiento en febrero de 1864.

Por otro lado, el capitán general Ramón María Narváez, obtuvo el título de duque de Valencia el 26 de noviembre de 1847, otorgado por la reina Isabel II como reconocimiento a sus servicios por su desembarco en Valencia en 1843, donde al mando de un ejército de moderados y progresista sometió a los últimos reductos del general Espartero, obligándole a exiliarse. El Espadón de Loja fue una importante personalidad que desempeñó un papel capital como jefe del Ejército, presidente del Gobierno o figura de la Oposición, y que, según afirmó Donoso Cortes, era la columna que sostenía el edificio, y que el día en que la columna cayera, el edificio entero se desplomaría ${ }^{9}$.

Fue el 16 de marzo de 1846, cuando Narváez ocupó por segunda vez el cargo de presidente del Gobierno, aunque tan solo duró 19 días, a pesar de que para una gran parte del moderantismo era un líder indiscutible ${ }^{10}$. El 4 de octubre del año siguiente, y por tercera vez, el lojeño retornó al cargo en un «Gobierno largo». En esta ocasión permaneció algo más de dos años. Controló la prensa, sin ser débil con los progresistas y eliminó las posibles conjuras revolucionarias ${ }^{11}$.

\footnotetext{
${ }^{6}$ Detalles de estos servicios se pueden ampliar en múltiples documentos del Archivo Palacio Real, Sección Reinados. Reinado de Fernando VII.

7 Archivo General del Ministerio de Justicia -AGMJ- Sección Títulos Nobiliarios, legajo 97-2 bis, expediente 86 a nombre del duque de Sevillano y marqués de Fuentes de Duero.

${ }^{8}$ www.senado.es.

${ }^{9}$ Jesús PABÓN Y SUÁREZ DE URBINA: Narváez y su época..., op. cit.,p. 51.

${ }^{10}$ Manuel SALCEDO OLID: Ramón María Narváez..., op. cit., p. 292. Durante estos años, se produjo, especialmente en Cataluña, una crisis agraria e industrial, que, unida a algunas reformas de los gobiernos moderados, supuso el levantamiento carlista conocido como «Guerra de los Matiners» o Segunda Guerra Carlista.

${ }^{11}$ Manuel SALCEDO OLID: Ramón María Narváez..., ibídem, pp. 326-328.
} 
Pero centrando la narración en la relación epistolar entre estas dos personalidades, el primer escrito que se ha localizado, y por sus formas, el primero que Juan de Mata Sevillano le dirigió al moderado general Ramón María Narváez, que se encontraba en Madrid, está fechado el 30 de julio de 1848. Comenzaba con un «muy señor mío» y trataba acerca de asuntos económicos entre un banquero y su cliente. Hay que destacar que conforme fueron pasando los años, Sevillano, como una forma de dejar patente que había pasado de ser un cliente a ser un amigo, se dirigió al lojeño con «mi querido amigo» y «mi apreciable amigo», y además de comentar en sus cartas temas totalmente íntimos y particulares, se escribían acerca de los regalos que mutuamente se entregaban en distintos momentos, y hacían exaltación de la amistad que se profesaban uno al otro.

Los días 24 y 28 de septiembre de 1848, Sevillano se dirigió al duque de Valencia adjuntando un escrito del alcalde de Vicálvaro, solicitando que intercediera sobre siete jornaleros de su villa condenados y deportados a Málaga, pero que eran inocentes e iban a ser llevados a Ultramar. No se ha visto el resultado de esta petición.

Sin embargo, el primero de enero de 1849, hizo mención del envío de unos cigarros que había remitido el banquero al militar. El 31 de julio, Sevillano le dio el pésame a Narváez por la muerte de su padre. Le añadió que sabía que esta muerte no iba a disminuir su entrega al país y a sus deberes. Hay que tener en cuenta que, en aquellos momentos, el general residía en Madrid, por ser presidente del Consejo de Ministros de España, cargo en el que se mantuvo hasta 1851.

\section{AÑOS 1851, 1852 Y 1853. MUCHAS OPERACIONES COMERCIALES}

El general Narváez había dimitido de la presidencia del Consejo de Ministros de España el 14 de enero de 1851, por lo que fue encargado de formar Gobierno el conservador Juan Bravo Murillo. Sevillano, el día 19, como una nueva muestra de adhesión, le escribió a su amigo diciéndole que estaba de acuerdo con que «haya dejado esto, a pesar de lo que piensen incautos y egoístas» y el 30 de enero, que no se podía hacer caso de "hablillas que siempre las hay de distintas personas (...) y que si se hubiera quedado en Madrid le habrían surgido miles de obstáculos y chismes, y que todos sus actos serían juzgados fuertemente». A los pocos días, el 21 de febrero, Sevillano insistía en los hechos de «estos señores que mandan» aprobaban leyes en 
el Senado, lo que le obligaba a enviarle sus comunicaciones por correo para evitar problemas con los curiosos. Con el transcurrir de los meses de este año 1851, Juan Sevillano se encargó de seguir manteniendo informado al Espadón de Loja de cualquier noticia política que se produjera en Madrid. Hablándole de O'Donnell, Andino, Pavía, de las votaciones en el Senado, de los senadores o sus intrigas dentro de cada grupo político, asegurándole a Narváez que era mejor que no estuviera en Madrid, así se vería claro que él no era quien originaba los líos. Le continuó diciendo que retrasara al máximo su retorno a la capital, porque «el terreno no está todavía preparado y hay que hacerlo con éxito, que pronto llegará por el bien del país» aunque insistiendo en que para cuando estuviera en Madrid le ofrecía su casa. Diciéndole, en otro momento, que él rechazaría el ofrecimiento que le pudiera dar para ocupar cualquier cargo público, ya que lo único que deseaba «es seguir contando con su amistad y seguir siendo útil al país y a los pocos hombres que le han sido simpáticos». Le daba noticias de España y «las posibles revoluciones, socialismo absoluto y por si acaso, contra los rojos» así como de Cataluña, Estados Unidos, Inglaterra, La Habana y Portugal «que no están buenos».

A partir de su salida de Madrid, era normal leer en las noticias políticas de la prensa que el general Narváez, cuando regresaba a la capital, se hospedaba en casa del marqués de Fuentes de Duero ${ }^{12}$. Por su parte, era el mismo Juan Sevillano el que, a pesar de recomendarle a su «muy querido amigo y dueño» que retrasara cuanto pudiera sus llegadas a la Corte, quien le invitaba a que cuando llegara a la capital se hospedara en su casa el tiempo que gustara, para lo cual, le ofrecía su palacio.

De estos tres años, se han localizado 254 escritos $^{13}$, algunos muy extensos, que Sevillano dirigió a Narváez. En estos, en contadas ocasiones, se dirigió al militar como «muy señor mío y dueño», asiduamente era con «mi querido amigo».

\footnotetext{
12 Se pueden ver, entre otras, las ediciones de El Heraldo (20-XI-1851), La Época (3-XII-1852), El Clamor Público (8 y 9-XI-1853).

${ }^{13}$ Se puede destacar que la mayoría de las cartas manuscritas y firmadas por Sevillano, en ocasiones escritas por alguno de sus dependientes, tienen en el ángulo superior derecho la nota de "contestada», y una fecha cercana a la que figuraba en el escrito recibido.
} 


\section{Correspondencia comercial}

Como ya se ha dicho, Sevillano tenía otros muchos clientes entre los más adinerados de la Corte, por tanto, es obvio que el capital que negociaba era considerable, de ahí que en la prensa madrileña fuera considerado en distintos momentos con el sobrenombre de: «el primer capitalista de nuestro país», "el capitalista», «el conocido banquero de la corte» 0 «el opulento banquero» ${ }^{14}$.

Hacer un esquema con las transacciones y sus importes que Sevillano mencionaba, así como las cotizaciones de los distintos valores, significaría incluir unas tablas de números que, muchas veces, además de resultar complicadas de confeccionar, no arrojarían ningún añadido al resto de explicaciones. Sin embargo, se citarán los grupos de alguna de estas operaciones que aportará una idea de la magnitud y variedad de las que se podían intercambiar en tan solo estos tres años. Asimismo, aunque en multitud de ocasiones Sevillano no citaba la cantidad de la que se componía la operación tratada, como muestra de una absoluta confianza mutua, sí se podrá tener una idea aproximada del elevado montante que se movía entre banquero y cliente. No obstante, a pesar de que muchas de estas cartas hablaban de asuntos comerciales, resulta imposible considerarlas por separado, porque en ellas se entremezclaban temas particulares o políticos, pero siempre, dentro de la afabilidad. Estas eran, en resumen, las operaciones:

-Letras sobre Granada y Málaga, por cantidades que sumadas sobrepasaban los 500.000.- reales de vellón, a veces endosadas por Sevillano a favor del duque de Valencia.

-Entregas en efectivo, habitualmente a Vicente Díez Canseco ${ }^{15}$, que ejercía como el apoderado de Narváez. La casa Sevillano también entregaba otros importes a los interlocutores que ordenaba el cliente. Estas entregas, además de los ingresos por el cobro por su cuenta de cupones o por amortizaciones de títulos vencidos, producían los movimientos en la cuenta corriente de su cliente en los libros contables de la casa del banquero vicalvareño. Así, el 2 de agosto

\footnotetext{
${ }^{14}$ La Carta (22-VII-1847). La Época (19-I-1851 y 14-IV-1853) y El Áncora (4-II-1851). El Clamor Público (24-XI-1852); La Época y La Esperanza (14-4-1853).

${ }^{15}$ A primeros de abril de 1852, Sevillano escribió a Narváez acerca de la mala salud del mencionado Canseco.
} 
de 1851, un apoderado de Sevillano le dijo al duque de Valencia que tenía un saldo a su favor de 4.401.865.- reales. No obstante, Sevillano le advirtió a Narváez que este sobrante lo iba a colocar en Londres, porque «prefiero menos intereses, pero más seguridad y no exponer capitales». Por el contrario, el 29 de febrero de 1852, escribió acerca de un giro que el lojeño había enviado para cubrir el descubierto de su cuenta, aunque el banquero le contestó diciéndole que no corría ninguna prisa, y que, además, en otras ocasiones había sido superior.

-Compraventa de obligaciones belgas, prusianas o austriacas, o papel sobre Londres.

-Cotizaciones de: letras; obligaciones; bonos; Deuda Flotante española; francos franceses; fondos austriacos, belgas y franceses; y de la Bolsa española, así como de otros efectos.

-Fondos ingleses para invertir el saldo que tenía el duque en la casa Rothschild que era de 43.700.000.- reales, y de las comisiones de esta casa; y de relaciones y negocios con Weissweiler. En abril de 1852, Narváez se había dirigido al barón de Rothschild diciéndole que el marqués de Fuentes de Duero pondría a su disposición una cantidad de francos, relacionada con ciertas rentas de Austria.

(Por otro lado, no se ha visto en ningún momento qué tipo de comisiones percibía el banquero madrileño de su cliente, si es que las percibía, por sus gestiones, asesoramientos y mantenimiento de cuenta).

-Problemas en el Tesoro Español y de la Deuda, cada vez con precios más bajos por las dificultades del Gobierno. Compraventa de Deuda española por distintas cantidades, citándose importes de más de siete millones de reales, pero con dificultad de hacer algunas operaciones por falta de dinero en la Bolsa, donde nadie pedía dinero, salvo el Estado, y que no funcionaba por falta de operaciones. El 3 de noviembre de 1851, llegó a decir que «el castillo que va a arder con perjuicio para todos los fondos».

-Asesoramiento para traer dinero que el general tenía en Francia y poderlo invertir en algún producto en España. Se citaron cantidades en francos y en «miles de duros», aunque Sevillano ya le había adelantado que no había nada 
interesante en donde invertir, y, precavidamente, le advertía que «nunca es prudente colgar mucha carne en el mismo garabato», aunque en otra carta añadía que él no era infalible. No obstante, sí debió facilitar muchos beneficios a Narváez, porque este insistía en pedir sus consejos financieros, que «siempre se los facilitaba de buena fe y deseos de éxito».

-Además, Sevillano no desaprovechaba la ocasión para, haciendo gala de sus conocimientos financieros y económicos que tan alto le habían llevado en la esfera social madrileña, indicar a su cliente sobre el negocio de una vajilla, que era de plata, cómo debía ser su entrada en España y la forma de no pagar impuestos, alegando que era la que usaba el duque de Valencia.

-Asesoramiento sobre la compra de unas fincas, o cualquier otra inversión.

-Mediación del marqués de Fuentes de Duero, ante el duque de Riánsares, el duque de Osuna y otros, en el asunto del Teatro Real y la inversión que allí había efectuado Narváez.

De todos estos escritos, se puede deducir que Sevillano, además de ser el banquero del Espadón de Loja, así como de otros muchos dignatarios madrileños, era su asesor, aunque siempre desde la prudencia, ya que tenía sumo cuidado al inducirle a realizar ciertas operaciones, además de que, dejaba claro, que las compraventas e inversiones, siempre diversificadas, se realizaban siguiendo las instrucciones de su cliente. De hecho, el 22 de julio de 1852, Sevillano ya le había dicho a Narváez que los buenos comerciantes no confundían negocio con amistad.

Se ha podido comprobar en la mayoría de los escritos que Sevillano hacía alusión a algunas de sus cartas anteriores, por lo que, sin lugar a dudas, y como un importante negocio que era el suyo, debía llevar un registro y borrador de lo que escribía, tanto al general, como al resto de sus clientes. Por tanto, y como ya se ha dicho, es un problema añadido no poder contar con los documentos que pudo conservar este banquero.

Una vez que se ha detallado de forma general el contenido de la correspondencia comercial que existía entre el cliente y el banquero se puede indicar que, como ya se ha adelantado, también existían escritos que eran tocantes a sus relaciones particulares de amistad, o que bien estaban imbuidos de los momentos políticos que se estaban viviendo en España. 


\section{Correspondencia política}

En el año 1851, Sevillano le remitió a su amigo y cliente, que en enero había dejado su puesto en la presidencia a Bravo Murillo $^{16}$, noticias relacionadas con el Senado, y sobre los esfuerzos de Salamanca para nombrar algún ministro. Se permitió decirle que en las circunstancias en las que estaba el país, era mucho mejor que él no volviera a mandar, aunque los progresistas fueran ganando puestos. Le advertía que no se fiara de algunas personas que le pudieran perjudicar, que había pocas personas en las que se pudiera confiar, y que según decían algunos, además de otras barbaridades, era que la reina quería que Narváez no fuera diputado y que renunciara a todo.

En marzo, Sevillano se congratuló de la amistad que los unía. Continuó haciendo referencia a la mala marcha del Gobierno y recordando los buenos servicios que había hecho el general al país. Asimismo, le indicó a su amigo que le había visitado O'Donnell y que le había confirmado su destitución. En mayo, Sevillano continuó mencionando la mala situación del país, insinuando una posible llegada de su amigo al Senado para asistir a las sesiones, para seguido marcharse a cuidar a su madre. Asegurando que el Gobierno nunca le llamaría ni a él ni a Espartero, salvo que hubiera pronunciamientos, y que según le decían otros senadores, Narváez podría gobernar durante mucho tiempo.

En el mes siguiente, Sevillano le continuó enviando noticias y cartas de otros políticos a su general, que en aquel momento estaba en Londres (más adelante, Narváez se trasladará a París). El primero de julio, del Senado y de los senadores que se iban de veraneo, añadiendo que, si le propusieran ser ministro, era algo que no querría por no considerarse con la aptitud necesaria. Por ese motivo, no haría a ningún Gobierno una oposición sistemática, por lo que quería ser independiente en cuanto al Gobierno y para con la oposición y así votar individual y libremente. Como una nueva muestra de su adhesión al general y al partido Moderado, aunque tratando de ser neutral ${ }^{17}$, agregó que, si el partido progresista llegase al poder y propusiera algo

\footnotetext{
${ }^{16}$ Este presidente, en 1851, de acuerdo con la reina, firmo el Concordato con la Santa Sede que serviría para la reconciliación de la Iglesia y el Estado español.

${ }^{17}$ Es preciso incidir en que Sevillano no se mostraba abiertamente de ninguna tendencia política.
} 
bueno, lo votaría a favor, diciendo que, aunque no viniera de su partido, le parecería bueno.

El 29 de octubre de 1851, Sevillano rechazó las alabanzas que le dedicaba el general, así como un nuevo ofrecimiento de cualquier cargo público, ya que, añadió, lo único que quería era seguir contando con su amistad y seguir siendo útil a su país y a los pocos hombres que le habían sido simpáticos. Concluyó diciendo que las cosas en España estaban muy mal «desde que el general se había salido».

Bravo Murillo continuó siendo presidente del Consejo de Ministros hasta finales del año 1852, que fue cuando presentó su dimisión a la reina, por haber perdido su confianza. El 14 de diciembre, le sucedió en el cargo otro militar, el general Federico Roncali.

El marqués de Fuentes de Duero era parte integrante de los moderados españoles, y él mismo lo anunciaba por su adhesión al general Narváez. No obstante, hasta finales de 1852, cuando los distintos periódicos recogían alguna información relacionado con Juan de Mata Sevillano, no se atrevían a encuadrarlo dentro de ningún partido. Pero fue el 24 de noviembre de este año cuando La Época hablaba del noble de Vicálvaro situándolo en el Senado enfrentándose, junto con otros compañeros, a la oposición progresista. A partir de este momento, era lo más habitual ubicar, sin ninguna duda, a Juan de Mata Sevillano y Fraile, marqués de Fuentes de Duero, dentro de la bancada de los moderados, o como componente del «partido monárquicoconstitucional», es decir el Partido Moderado ${ }^{18}$.

En alguna de sus cartas, Sevillano mencionaba otros escritos que le había enviado con ciertas noticias, aunque había veces que, aunque no sucediera nada digno de decir, le escribía para saludarle. En otras terminaba apuntando que Narváez obraba bien como lo que estaba haciendo, aunque era con provecho para otros políticos, y no en el propio.

Por su parte, en febrero de 1852, Juan Sevillano que, a través de sus escritos, continuó revelando cómo iba incrementándose su amistad, también se encargó de

\footnotetext{
${ }^{18}$ El Heraldo y La España (14-XII-1852).
} 
comunicarle de primera mano a su querido amigo los pormenores del atentado que había sufrido la reina y del estado de S.M. ${ }^{19}$.

Conforme iban transcurriendo los meses, Sevillano se mostró cada vez más unido en todos los sentidos a Narváez, de hecho, parecía su aliado, su corresponsal, su emisario, en definitiva, que se proclamaba encargado de comunicar al general todos los acontecimientos de índole política que sucedían en la Corte. Así, le escribía sobre asuntos relacionados con la forma de actuar del general en aquel momento, añadiendo que, en la próxima legislatura, en su modesta opinión, le convenía venir, que habría oposición también en el Senado. Le hacía mención acerca del patriotismo, lealtad y demás opiniones políticas.

En septiembre, Sevillano le dijo a Narváez que estaba proyectando hacer un viaje a Daimiel para vigilar unas posesiones que tenía en la zona, por lo que, añadió que deberían ponerse de acuerdo para reunirse en Puerto Lápice «para darse un abrazo». A pesar de no tener más datos de esta reunión, a los pocos días, el banquero le apuntó al general que cuando regresara a Madrid llevaría a efecto todos los encargos que le había encomendado, sin especificar cuáles eran estos. Más adelante, le comentó que había recibido un anónimo que les enjuiciaba a los dos y que posiblemente hiciera referencia a su entrevista en tierras manchegas. No obstante, le dejó bien claro que él no hacía caso de los anónimos. De hecho, en las siguientes cartas le escribió sobre otros anónimos recibidos en su casa en los que, en uno de ellos, insultaban fuertemente al futuro marido de su hija, el conde de Goyeneche, acusándole de tacaño y de que su capital lo había conseguido con las comisiones, por ser agente de los jesuitas, «además de otras lindezas», concluía Sevillano. En otro, que se lo adjuntaba al general, continuaban criticando a Goyeneche y al propio banquero que, al ir a casar su hija con el noble, le acusaban de sus deseos de acumular títulos y otras calumnias parecidas ${ }^{20}$. De hecho, Sevillano se encontraba dentro de la elite económica que había llegado muy alto en la escala social como consecución de negocios con el Estado, y que, para estar en consonancia con el resto

\footnotetext{
${ }^{19}$ En febrero de 1852, la reina Isabel II había sufrido un atentado perpetrado por el riojano conocido como el cura Merino. Una vez recuperada, esta fue ovacionada en las Cortes, como una forma de mostrar su temor porque le pasara algo.

${ }^{20}$ Se puede recordar que, en su interés por estar cada vez más introducido en la nobleza, en febrero de 1846, Sevillano había casado a su hija María de las Nieves con el conde de Vega del Pozo y marqués de los Llanos de Alguazas.
} 
de la nobleza madrileña, en 1846, había ordenado la construcción de un palacete en la calle Jacometrezo, que, por su lujo, pronto llamó la atención en la capital ${ }^{21}$.

El 8 de octubre de 1852, Sevillano le escribió al duque de Valencia comentando asuntos políticos sobre la reunión de las Cortes y alabando la decisión de Narváez de no trasladarse a Madrid, porque, según su parecer acerca de la situación, así se ahorraba el viaje. A los pocos días, en una de las cartas que casi a diario le enviaba, ensalzaba a Narváez como un importante servidor de España, y ampliando sus elogios con que les unía «una íntima relación de amistad».

El día 22 de noviembre, porque Narváez le había comunicado a Sevillano que pensaba viajar desde Loja a Aranjuez y a Madrid, el banquero le indicó que hiciera lo que considerara mejor, dándole a continuación la situación del Senado, institución que el militar proyectaba visitar. Al día siguiente, Sevillano volvió a citar la posible visita de su amigo a Madrid y a la Cámara Alta. También, el día 25, con la visita al Senado aparentemente aplazada, Sevillano le confirmó que él no era amigo de esperanzas políticas, sino de fundamentos firmes. El día 26, el vicalvareño escribió nuevamente sobre la posible llegada del duque de Valencia a Madrid, la cual, añadía, aumentaría la tensión en el Senado, así como que causaría problemas en el Congreso y haría más significativa la oposición en el país, por lo que, en ciertos lugares, apuntaba, deseaban que no viniera.

Es necesario tener en cuenta que, además de sus asesoramientos comerciales, de los que tanto se ha hablado más arriba, el marqués de Fuentes de Duero también trataba de incidir en las posibles tomas de decisiones del general a nivel político, cuando estaba apartado de la Corte.

El mismo día uno de enero de 1853, el marqués le escribió a Narváez, que permanecía en Francia, dándole pormenores de la oposición, citando sus contactos con O'Donnell, Hormaechea y otros, como si de un corresponsal se tratara, añadiendo que era mejor que no regresara a Madrid, que el general Serrano se estaba acercando a él. Le habló de «dimes y diretes» de otros que querían que se los hiciera seguir al

\footnotetext{
${ }^{21}$ Archivo de la Villa de Madrid, signatura 4-47-111. Expediente titulado "Licencia a don Juan Sevillano para edificar sus casas calle de Jacometrezo, 18, 20 y 22, manzana 355, con vuelta a la del Carbón" con documentos que Sevillano y su arquitecto tuvieron que suscribir para ejecutar esta obra, así como las contestaciones oficiales de los distintos servicios municipales. Así como un plano del palacio.
} 
general. A finales de marzo, le dijo que, en abril, el general estaría en libertad de acudir a la capital, si así lo seguía deseando.

No obstante, en sus escritos, el marqués de Fuentes de Duero solía ser prudente, y en muchas ocasiones, no citaba nombres, por miedo al correo, ya que, según denunciaba, sus cartas habían llegado en más de una ocasión abiertas. En abril, continuó escribiendo de personalidades relevantes en la política nacional, nombrando actuaciones y opiniones hacia Roncali, O'Donnell, San Miguel, Espartero o Serrano, entre otros, así como de las discusiones en el Senado; asimismo, de la llegada de Narváez a España. Sevillano continuó escribiendo sobre algunos gobernantes, sin decir su nombre, y de «la cerradura de las Cortes».

Ante una hambruna que sufrían las provincias gallegas, el banquero, con su habitual altruismo, aportó dos mil reales para ayudar a paliar la desgracia ${ }^{22}$. Para defender a su amigo el general Narváez, Sevillano, el 27 de abril de 1853, se encargó de decirle que Espartero había hecho una aportación de mil reales, y que los progresistas se habían encargado de hacer pública de forma amplia esta entrega, por lo que le sugería a su amigo que hiciera una superior. De esta manera, en su nombre, él mismo había dado mil quinientos reales. Al día siguiente le participó que en el Diario de Avisos se publicaba la lista con los donantes y que Narváez «aparecía delante del otro» (Espartero) porque la relación se hacía por orden de importes entregados. Terminaba hablándole de «las desgracias de las provincias gallegas, Santiago, Orense y Pontevedra, donde sus gentes emigran a Portugal o comen yerba».

En los meses siguientes, Sevillano siguió enviando información relacionada con la política nacional, aunque, cuando citaba a algún protagonista, lo hacía solo por la inicial de su apellido. En junio, le comentó la composición del nuevo gabinete, con nombres como Pidal y Mon; y que él podría estar donde quisiera, de hecho, el general se había trasladado a Puertollano a tomar las aguas. En diciembre, que estaba en Aranjuez, relacionadas con «los líos» del Senado y del Congreso, volviendo a decir que era mejor que no estuviera, así verían que no era él quien los originaba. Añadiendo opiniones y habladurías, pero pidiéndole que no hiciera ninguna oposición al Gobierno moderado. Para finalizar el año, con felicitaciones, envío de regalos de

\footnotetext{
${ }^{22}$ En la prensa de los meses de abril y mayo de 1853, era frecuente leer noticias relacionadas con la catastrófica situación por la que estaban pasando las provincias gallegas.
} 
cajas de cigarros y críticas hacia Sartorius. Durante dos meses, Narváez permaneció en Aranjuez, y, como verdadero hombre de Estado, aunque no se implicaba públicamente en la vida política, su caserón era un importante centro de deliberación y actividad política ${ }^{23}$.

\section{Correspondencia familiar-particular}

En mayo de 1851, mostrando su aparente tendencia política, Sevillano se había dirigido al general Narváez diciéndole que el Concordato que había firmado Bravo Murillo había caído mal «hasta a nuestros moderados» y añadiendo que a él «no le haiga (sic) salido algún cargo».

El 3 de marzo, Sevillano declinó la invitación de Narváez para que ir a visitarle a su casa. Para justificar su negativa, el banquero alegó que: «no conozco ninguna de mis posesiones compradas hace mucho tiempo en este país, por falta de tiempo libre para verificarlo», y comentando los acontecimientos de esos días, el noble vicalvareño añadió «dicen que el diablo sabe todo, y que este toma chocolate conmigo todas las mañanas y me lo cuenta».

El 24 de junio, Sevillano le escribió sobre unos vinos que le había regalado. En agosto, conociendo Sevillano que Narváez iba a trasladarse a Madrid, camino de su Loja natal, le ofreció en repetidas ocasiones su casa, en donde, se podría quedar tanto tiempo como deseara. En septiembre, confirmó la invitación, aunque prefiriendo que retrasara su llegada a la Corte y que debería completar el año entero de su licencia, a la vez que le mencionó la insalubridad de Aranjuez. En octubre, Sevillano, contento por el retraso de la llegada de Narváez a Madrid, continuó ofreciéndole su casa «que no es digna de un general» y le recordó que la vez anterior que estuvo en su casa fue bien acogido por todos, incluso por los contrarios, ya que él era «una persona sin pretensiones políticas y sin ambiciones de ningún género, y que no estaba capacitado para los negocios de la política».

Las relaciones entre los dos amigos continuaban incrementándose. El duque de Valencia había partido hacia su ciudad natal en enero, pasando por Aranjuez ${ }^{24}$. El

\footnotetext{
${ }^{23}$ Manuel SALCEDO OLID: Ramón María Narváez..., op. cit., p. 504.

${ }^{24}$ El 9 de enero de 1852, en Aranjuez, una partida de amigos le dedicó una cordial despedida, en Manuel SALCEDO OLID: Ramón María Narváez..., op. cit., p. 462.
} 
marqués de Fuentes de Duero, en marzo, al haber fallecido la madre de Narváez, por cuya salud venía preguntando desde hacía meses, le escribió con palabras de sentimiento por la pérdida.

El 24 de abril de 1852, Sevillano le escribió a su amigo, que continuaba en Loja, declinando nuevamente la invitación que le hacía para que le visitara en su ciudad natal, porque, decía, tenía muchas ocupaciones. En otros momentos, aunque habitualmente el banquero no hacía referencia a donde se encontraba el duque de Valencia, sí se ha visto que, por ejemplo, en septiembre estaba en Puertollano y en diciembre en Bayona.

El 19 de junio, el escrito era sobre que su hija Nieves había tenido «una robustísima niña»; y el 25 de julio, que se iba a casar su hija «Mariquita». De igual manera, le dio datos del pretendiente, el conde de Goyeneche, para que dijera si era de su gusto. El 19 de noviembre, volvió a comentarle la boda de su hija con este conde, a la vez que siguió invitándole a su casa en Madrid, en donde la marquesa estaría encantada de tenerlo de nuevo, y el 28 de octubre, que se había celebrado la boda de su hija, y que esta, en tan importante día, le mandaba cariñosos saludos ${ }^{25}$. A los pocos días, además de los saludos, le acompañó una carta de su yerno. En otros escritos posteriores, Sevillano no olvidaba incluir entre su contenido los recuerdos que su hija y el conde de Goyeneche mandaban para el general.

El 2 de agosto, Sevillano le escribió a Narváez haciendo una exaltación de la amistad y sobre que él aumentaba su mérito, ya que se sentían muy amigos y que simpatizaban, además de estar orgulloso de haberle hecho sus servicios.

Al inicio de la primavera de 1853, Sevillano comentó el mal estado de salud de su esposa, y que los facultativos no veían una solución. Así que el 10 de abril, se produjo el fallecimiento de la marquesa de Fuentes de Duero. A su entierro y exequias acudieron los más importantes capitalistas, senadores, diputados y los representantes de las primeras casas de la Grandeza española, así como políticos ligados con «el opulento banquero» ${ }^{26}$. El propio marqués le dio a Narváez la noticia de la muerte de su esposa, tras una enfermedad que tan solo había durado seis días, añadiendo también

\footnotetext{
${ }^{25}$ La Época (31-10-1852) recogía detalles de esta ostentosa celebración.

${ }^{26}$ El Heraldo de Madrid y La Esperanza (12 y 15-IV-1853), Gaceta de Madrid (13-IV-1853) y La Época (14 y 26-IV-1853).
} 
detalles de los funerales y los apoyos recibidos, y hablando de los sentimientos, tanto suyos como de sus hijas y sus maridos, por la pérdida de la marquesa.

\section{AÑO 1854. DÍAS DE GRAN INTENSIDAD}

Este año fue profuso en acontecimientos que propiciaron que Juan de Mata Sevillano le escribiera al duque de Valencia en 112 ocasiones. Eran unas cartas, enviadas casi a diario, en las que su contenido se mezclaba los temas financieros y los domésticos con la actualidad política del momento. Una prueba de la casi diaria correspondencia se podía ver en la carta del 19 de abril, cuando Sevillano manifestó su extrañeza porque llevaba tres días sin recibir carta del general.

El 5 de enero le comunicó que S.M. la reina había parido una niña, por lo que habían llevado a su casa un pliego para que Narváez acudiera al bautizo de la infanta, pero que finalmente no lo dejaron. Este intento de entrega evidenciaba que en Palacio se debía considerar que el domicilio del general en Madrid era la casa del banquero.

En los seis primeros meses de 1854, los escritos que dirigió el banquero a su general dándole puntual y casi diario conocimiento de los sucesos políticos en Madrid, estaban llenos de claves de difícil interpretación. Le habló de: «el sujeto», «el D», «el $P$ », «el G» y «el S», a la vez que mezclaba estas iniciales con nombres como Andino o don Pedro, le dio noticias de los sucesos relacionados con el Gobierno, apuntando que utilizaba estas letras para contarle «la chismografía» por miedo al correo. De hecho, le volvió a escribir sobre anónimos recibidos criticando a distintas personas cercanas a él. En mayo, Sevillano haciendo referencia a la guerra de oriente, mostró su dolor por el derramamiento de sangre e hizo un razonamiento en contra de la guerra, dejando claro que era enemigo de la violencia. ${ }^{27}$ El 21 de junio, Sevillano le dijo a Narváez, que estaba en Loja, que, aunque no tenía nada que contarle, le escribía para darle fe de vida y preguntarle por si se había recuperado de su indisposición. El día 29, justo al día siguiente de La Vicalvarada y temiendo que le fueran a atrapar, el marqués de Fuentes de Duero le había escrito al exiliado general Narváez diciéndole que «después de ponerme a la sombra por el mucho sol, si al gobierno le molesta mi presencia, ni hiré (sic), siempre que sea donde yo quiera y que me den algunos tiempos para arreglar

\footnotetext{
${ }^{27}$ Sevillano se debía referir a la Guerra de Crimea, en la que estuvieron alistados unos 900 soldados españoles, en su mayoría, antiguos combatientes carlistas, en José Enrique LÓPEZ JIMÉNEZ, «Españoles en la Guerra de Crimea», Ejército de Tierra Español, núm. 834, octubre 2010, pp. 104-109.
} 
mis negocios». Al día siguiente, Sevillano volvió a preguntarle a Narváez sobre su salud, a la vez que le mandaba saludos de sus hijos, que estaban en Francia. No dejando de ser extraño el contenido de esta última carta, después de lo que había dicho el día anterior. No obstante, no se conserva ningún escrito remitido por Sevillano a Narváez desde este 30 de junio hasta el 9 de julio, que se dirigió a su amigo para continuar hablando de la deteriorada salud del general.

La ausencia epistolar que se ha mencionado, desde el 30 de junio hasta el 9 de julio, cuando se ha visto que se escribían casi a diario, podría ser motivada porque Sevillano, además de estar temeroso por su posible detención, que finalmente se produjo el 7 de julio, a pesar de que, en aquel momento, era un militar retirado ${ }^{28}$, es decir un civil que, oficialmente, no había tenido ninguna implicación directa con el movimiento.

Pues bien, fue el 28 de junio, en los campos de la villa cercana a Madrid de Vicálvaro, cuando se produjo el levantamiento conocido como "La Vicalvarada». Golpe militar moderado, que se venía fraguando desde hacía varios meses, con motivo de la corrupción que imperaba en un Gobierno, también moderado, dirigido por Luis José Sartorius, porque temían que los escándalos salpicaran a la propia reina Isabel II. Los protagonistas de esta sublevación fueron los generales O'Donnell, Ros de Olano, Mesina y Dulce, que contaban con el apoyo de políticos conservadores como Cánovas del Castillo, Ríos Rosas y otros ${ }^{29}$. Los mencionados mandos militares, como muestra de su adhesión a Isabel II, hicieron desfilar a sus tropas por las explanadas de la villa vicalvareña al gripo de «Viva la reina» ${ }^{30}$.

\footnotetext{
${ }^{28}$ En la obra citada de Agustín FERNÁNDEZ ESCUDERO: El negocio de la política..., se da cuenta de la vida militar de Juan de Mata Sevillano, que, si bien dejó el Ejército en 1815 para dedicarse a sus negocios de suministrador, en 1824 se le citaba como «teniente graduado como teniente coronel retirado, en clase de dispenso» y en 1832 se le concedió el título de "coronel graduado de Caballería retirado».

29 José Ramón URQUIJO Y GOITIA: La Revolución de 1854 en Madrid, Instituto de Historia Jerónimo Zurita, Madrid, 1984, p. 568. Francisco CÁNOVAS SÁNCHEZ: «Los partidos políticos» en La era isabelina y el sexenio democrático, tomo XXXIV de la Historia de España de Menéndez Pidal, Espasa Calpe, Madrid, 1981, pp. 453-454.

${ }^{30}$ José Fernando MERINO MERCHÁN y Óscar Ignacio MATEOS DE CABO: La "Vicalvarada”: 140 años después. Aproximación al significado jurídico-constitucional del Bienio Progresista (1854-1856), Congreso de los Diputados, Madrid, 1994, pp. 130 y 143-149. En este trabajo se pueden leer pormenores de los enfrentamientos que se produjeron en Vicálvaro entre las tropas leales y las sublevadas. Luis BARTOLOMÉ MARCOS et al: Historia de Vicálvaro, Ayuntamiento de Madrid, Madrid,
} 
Por otro lado, hay autores, como Salcedo, que apuntan que Narváez fue el autor y primer promotor de la idea de un alzamiento para acabar con la conflictiva situación política, que culminaría con La Vicalvarada. En sesiones del Senado de mayo de 1857, O’Donnell trató de atacar y deslegitimar al Espadón de Loja que se presentaba como promovedor de la labor restauradora de este alzamiento, con preguntas envenenadas $^{31}$.

Hay que decir que, en aquel momento, ante la grave crisis económica y la represión moderada, algunos hacendistas y banqueros españoles trataban de financiar cualquier tipo de sublevación militar, con el fin de que los militares, que tenían la llave de cualquier cambio, les apoyaran en sus aspiraciones políticas y en las posibles reformas que se pudieran aprobar ${ }^{32}$.

Según algunos autores, en esta sublevación tuvo su participación el propio capitalista Sevillano. Pablo Herce escribe que «dicen que la Vicalvarada se gestó en el domicilio de Juan de Marta Sevillano», y que incluso este llegó a financiar la misma, aunque, según este autor, no existen pruebas de esta afirmación ${ }^{33}$; por su parte, Corral indica que la participación de Sevillano en este pronunciamiento fue decisiva y que desde su palacio se gobernó la revolución ${ }^{34}$; Kiernan abunda en el tema diciendo que parece ser que algunos banqueros, entre los que encontraba «el duro conservador Sevillano» suscribieron una cantidad de dinero para la compra de armas ${ }^{35}$. No obstante, se puede asegurar que, entre todos los documentos investigados, no se ha encontrado ninguna información que corrobore estas afirmaciones, aunque sí se puede decir que, entre la correspondencia mantenida entre el vicalvareño y el duque de Valencia, por la que le informaba de todos los acontecimientos que sucedían en el

1987, pp. 114-118, también incluyen detalles de estos enfrentamientos e incluso alguna anécdota acaecida.

${ }^{31}$ Manuel SALCEDO OLID: Ramón María Narváez..., op. cit., p. 505 y pp. 576-579.

32 Vicenta María MÁRQUEZ DE LA PLATA y Luis VALERIO DE BERNABÉ: El libro de otro de los duques, Prensa y Ediciones Iberoamericanas, Madrid, 1994, p. 367.

33 Pablo HERCE MONTIEL: La Duquesa de Sevillano y su obra social, Institución Provincial de Cultura Marqués de Santillana, Excelentísima Diputación Provincial y Excelentísimo Ayuntamiento de Guadalajara, Guadalajara, 1999, p. 34.

34 José del CORRAL: «El duque de Sevillano y el marqués de Linares. Dos financieros madrileños del XIX», en José del Corral et al, Personas y personajes de la vida madrileña: su época y su historia, Cámara Comercio e Industria, Madrid, 1991, p. 23.

${ }^{35}$ Victor Gordon KIERNAN: The revolution of 1854 in Spanish History, Oxford at the Clarendon Press, Oxford, 1966, p. 48. 
terreno madrileño, no aparece en ningún momento referencia alguna a esta sublevación, claro que, como se ha dicho, desde el día 30 de junio hasta el 9 de julio no se han conservado escritos, y quedan dudas de que existieran estos. Asimismo, no deja de ser probable que, tratando de no incriminarse, y. tal vez conociendo la opinión del general, según dice Salcedo, Sevillano tampoco le hubiera escrito nada referente al alzamiento.

Es preciso indicar que, a pesar de su amistad con Narváez y sus declaradas opiniones en favor de los moderados, en aquel verano, y con motivo de algunas de sus declaraciones, Juan de Mata Sevillano aparecía encuadrado, según autores y distintos periódicos, entre los militantes del Partido Progresista, aunque lo cierto es que el capitalista vicalvareño, en todo momento, se presentó así mismo ante la sociedad de su tiempo como un prohombre de la patria alejado de radicalismos ${ }^{36}$. No es extraño esta sospecha de la prensa, ya que a este Partido Progresista, fundamentado en las clases medias con propietarios, comerciantes, intelectuales y profesionales liberales, pertenecían, entre otros, las personalidades de la burguesía más destacados, como Collado, Matheu o Murga, además de los políticos Madoz o Prim ${ }^{37}$. En los días siguientes a este golpe militar, los periódicos madrileños que se había encargado de ir recogiendo todos los acontecimientos también publicaban los premios que habían recibido los oficiales que habían sido capaces de sofocar la sublevación de los rebeldes $^{38}$.

Con el transcurrir de los meses, en diciembre de 1854, se aseguraba que algunos capitalistas como José Manuel Collado, habían comprometido su fortuna en esta aventura iniciada en Vicálvaro, aunque no se hacía mención de Juan de Mata Sevillano ${ }^{39}$. No obstante, se afirmaba que el pueblo había reaccionado con indiferencia

\footnotetext{
${ }^{36}$ Agustín FERNÁNDEZ ESCUDERO: El negocio de la política..., op. cit., p. 83.

${ }^{37}$ Francisco CÁNOVAS SÁNCHEZ: «Los partidos políticos..., op. cit., p. 419.

${ }^{38}$ Se pueden leer estas noticias y las condecoraciones a los vencedores en las ediciones de los primeros días de julio de 1854, entre otros, en El Heraldo, La Iberia, El Diario Oficial de Avisos de Madrid, La Esperanza y El Católico.
}

${ }^{39}$ La Época (29-diciembre-1854). 
ante esta insurrección conservadora, que con el Manifiesto del Manzanares cambió el sentido del alzamiento ${ }^{40}$.

A los pocos días de La Vicalvarada y del Manifiesto del Manzanares, en las principales capitales españolas, entre otras en Madrid, Barcelona, Valencia, Valladolid o Sevilla, surgieron movimientos revolucionarios ${ }^{41}$. El 17 de julio, a la salida de los toros, estalló un motín con el grito de «libertad y justicia» que sembró la capital de sangre y barricadas controladas por los progresistas. Era una protesta que quería derrocar un régimen político que perseguía la libertad y la tecnocracia y que cada vez se parecía más al absolutismo de Fernando $\mathrm{VII}^{42}$. También protestaba contra unos sectores del partido moderado que, como núcleo del poder económico, se había formado alrededor de la familia real para conseguir hacer negocios. Hay que señalar que muchas de las fortunas que surgieron en Madrid en las décadas de los treinta y cuarenta del siglo XIX, tenían su origen en los aprovisionamientos al Ejército de la reina durante la guerra civil carlista ${ }^{43}$.

En este levantamiento progresista y popular, el marqués de Fuentes de Duero sí se puede asegurar que tuvo una importante participación pública, dado que, desde un principio la estuvo financiado en gran parte, además de que fue precisamente en su palacio donde, el general San Miguel, huyendo de las turbas, se reunió junto con varios prohombres madrileños progresistas, demócratas y odonnellistas ${ }^{44}$, y formaron la Junta de Salvación, Armamento y Defensa de la Capital, con la idea de dirigir la revolución. El liberal general Evaristo San Miguel fue nombrado presidente de esta Junta, y como vicepresidente, Juan de Mata Sevillano. Sin embargo, como apunta Urquijo, las revueltas callejeras tenían como compañeros a progresistas y a moderados, pero

\footnotetext{
40 Joaquín TOMÁS VILLARROYA: «El proceso constitucional», en La era isabelina y el sexenio democrático, tomo XXXIV de la Historia de España Menéndez Pidal, Espasa-Calpe, Madrid, 1981, p. 261.

41 José Ramón URQUIJO Y GOITIA: La Revolución de 1854 en Madrid..., p. 81.

42 Guillermo G. CALLEJA LEAL, «Las revoluciones de 1854 y 1856 en Madrid», en Revista Historia Militar, núm. 87, año 1999, pp. 11-62.

43 Jesús Cruz, Los notables de Madrid..., p. 157.

44 José Ramón URQUIJO Y GOITIA: La Revolución de 1854 en Madrid..., pp. 137/139, ofrece un detalle completo de los componentes de esta Junta. Guillermo G. CALLEJA LEAL, «Las revoluciones de $1854 \ldots$... pp. 11-62, señala que en casa de Sevillano se había creado la junta más aristocrática que, uniéndose a la democrática de Toledo, se adueñaron de Madrid.
} 
ambos empeñados en mantener a la reina y su corona como máxima institución del régimen burgués ${ }^{45}$.

El 21 de julio, doce días después de la última carta, Sevillano, haciendo referencia a otras misivas que no aparecen en los expedientes, argumentó que no tenía tiempo, ya que la vicepresidencia de la Junta y la presidencia en la comisión de Hacienda de esta, no le dejaban un minuto, además de las idas a Palacio, desde donde las reinas, madre e hija, como dice Urquijo, al conocer los hechos con la falta de gobierno y la creación de las juntas emitieron un Real Decreto ${ }^{46}$. Apuntó que no le contaba lo que le había ocurrido, continuaba Sevillano, que era muy largo y que lo haría cuando se vieran personalmente. Añadiendo que O’Donnell estaba algo enfermo y que no se sabía nada de Espartero. Incluyendo al final que el general San Miguel merecía todo el reconocimiento por los esfuerzos que él había seguido muy de cerca.

La revolución en Madrid concluyó el sábado 29 de julio con el famoso abrazo en el balcón de la madrileña casa de Matheu entre los generales Espartero y O'Donnell ${ }^{47}$, a los que el marqués de Fuentes de Duero, con su protagonismo y representando a la Junta, había ido a recibir a Alcalá de Henares al primero y a Tembleque al segundo.

El 2 de agosto, otra vez con muchos días de vacío epistolar, Sevillano le escribió a Narváez citando su labor en la Junta, alabándose a sí mismo, por su esfuerzo. En su carta confirmó que había atendido a todas las necesidades sin soltar un solo maravedí contra el Tesoro. Le comentó acerca de sus reuniones con O’Donnell, y que este le había dicho que quería a Narváez más que Narváez a él. Sevillano le escribía sobre el mal estado de O’Donnell, y que este aseguraba que le escribiría a duque de Valencia inmediatamente. Nuevamente aprovechaba la ocasión para preguntar por su salud y desearle que se curara con las aguas de Puertollano. Asimismo, señaló que «no vaya fuera de Madrid, en manera alguna, amigo mío, que no es momento de exponerse a siniestras interpretaciones». Ahora, continuaba, contra él nada se decía y nadie desconfiaba porque no había motivo, por lo que debía esperar y «alinese» en lo posible al movimiento de las circunstancias, y más después de lo

\footnotetext{
45 José Ramón URQUIJO Y GOITIA: La Revolución de 1854 en Madrid..., pp. 208 y 212.

${ }^{46}$ José Ramón URQUIJO Y GOITIA: La Revolución de 1854 en Madrid..., ibídem, p. 97.

${ }^{47}$ La mayoría de los periódicos madrileños daban cumplida cuenta del cambio de la situación y de los abrazos entre los generales. Por ejemplo, La Época en su edición del 31 de julio, detallaba impetuosa y ampliamente todo lo sucedido.
} 
maltratado que él había sido. Citaba la buena actuación del Gobierno y de O’Donnell, del programa de Manzanares, que era como una llamada a los principios progresistas. Que pensaba que su amigo había escrito al general San Miguel para felicitarle por la labor realizada. Al día siguiente, Sevillano se quejó de que no atendía sus negocios y que no cobraba vencimientos por falta de tiempo. Añadiendo que, si la Junta hubiera sido creada antes, no se habrían producido desmanes, y que él había favorecido a muchas casas y particulares. Que el rey y la reina le habían llamado, y él les habló de su lealtad, y del trabajo de la Junta para restablecer el orden. También le dijo que había rechazado el Ministerio de Hacienda que se le habían ofrecido, porque le parecía difícil y por la falta de programa, que, además, estando en una corporación popular no quería que se dijese que la utilizaba en beneficio propio al aceptar el ministerio.

En la carta del 12 de agosto, Sevillano escribió a Narváez acerca de su aportación para la estatua del general San Miguel y para los heridos en la revolución. Asimismo, Sevillano criticó a algunos amigos de Narváez en Madrid.

En los siguientes días de agosto, Sevillano, que continuó haciendo referencia a la actuación de O’Donnell y sus buenos deseos hacia Narváez, que decía que ya había purgado todos sus pecados con su trabajo para el orden y el país, que incluso la propia reina decía lo mismo, cuando le preguntó por Narváez. No obstante, volvió a indicarle que no sería conveniente que volviera a Madrid, para evitar "siniestras interpretaciones». Difícil de entender estas últimas palabras. El día 24, Sevillano le comentó que la prensa quería saber cual era la posición de Narváez en la nueva situación que estaba viviendo la nación. Le volvió a decir que la reina le había llamado y le agradecía sus servicios prestados al trono y que quería darle una prueba, aunque, apuntó Sevillano que él le había dicho que con el reconocimiento real tenía suficiente. No obstante, a los 10 días, la reina le mandó la llave de Gentilhombre de Cámara en Ejercicio. Sevillano añadía que la reina no había consentido que pagara los impuestos de este nombramiento, porque había sido una gracia espontánea real.

En septiembre continuó la misma tónica. Sevillano siguió dando novedades de los acontecimientos en Madrid a su amigo, de los saludos que le enviaba O'Donnell, así como de las actuaciones de este militar en el Ministerio de la Guerra. Asimismo, se congratulaba de la licencia que el Espadón de Loja había recibido, y de su viaje a Francia, facilitándole domicilios en el país vecino a los que podía acudir en su nombre. 
El día 8, Sevillano le comunicó a su amigo que la reina, a propuesta del Gobierno, le había elevado a la dignidad de Grande de España de primera clase. Otro nuevo reconocimiento a su entrega. De igual manera que había recibido el nombramiento del ducado de Sevillano ${ }^{48}$.

En octubre de 1854, el ya duque de Sevillano obtuvo su triunfo en las elecciones constituyentes, siendo uno de los candidatos más votados en la capital.

En las sucesivas cartas de octubre y noviembre, Sevillano continuó hablando del viaje de Narváez por Francia y le preguntaba constantemente sobre su estado de salud, a la vez que, como venía siendo habitual, le enviaba los saludos de O'Donnell. En algunas cartas, le confirmó que no había noticias dignas de reseñar, aunque algunos periódicos, que decían ser amigos del general, publicaban rumores, con malicia y deseos de perjudicarle, relacionados con sus viajes y su próximo traslado a Loja, pero pasando por Madrid, donde Sevillano, como era costumbre, le ofrecía su casa. No obstante, el duque de Sevillano, tal vez para evitar falsas interpretaciones de algunas publicaciones, le confirmó que ellos dos en política no estaban divididos y que además les unía una fuerte amistad. Como noticia triste, le notificó que Diego, el marido de su hija, que estaban en Francia, tenía importantes problemas de salud.

Las noticias publicadas seguían siendo muy contrarias al duque de Valencia, por lo que Sevillano le comentó que no debía estar muy contento con el partido Moderado. Sevillano le continuó diciendo que, aunque hubiera decidido presentarse a diputado por su provincia, no hubiera sido elegido. Además, añadía que sería mejor que tardara varios meses en regresar a Madrid, que mejor lo hiciera a Barcelona o a Sevilla, hasta que se aclararan las cosas y que así se lo recomendaban también otras personas amigas.

El 22 de noviembre, Sevillano le comunicó a Narváez que Espartero había presentado su dimisión, y que la reina la había aceptado. Aunque al momento continuó en el cargo. Sevillano, como una labor más, continuó facilitando noticias de los acuerdos en el Congreso. A la vez que le comentaba las publicaciones de la prensa, haciendo referencia a lo que había declarado su amigo en su «El manifiesto que hace el General Narváez a los españoles» y sobre otras manifestaciones acerca de la

\footnotetext{
48 El nombramiento oficial tiene fecha del 6 de diciembre de 1854, y una copia se encuentra en el Archivo Histórico Nacional, Sección Consejos 8984, exp. 293, signatura 1854.
} 
situación internacional en Cuba, Inglaterra, Gibraltar o Francia. En los primeros días de diciembre, todo continuaba igual, con Sevillano facilitando a Narváez, que seguía en Francia, noticias de España y del marido de su hija, así como de la repercusión de su manifiesto y otros sucesos en la nación.

Siendo presidente del Consejo de Ministro el liberal Espartero, una vez que ya había tomado posesión de su escaño en el Congreso, el 8 de diciembre, Sevillano fue nombrado como ministro de Hacienda, aunque no se ha visto que se lo comunicara a Narváez hasta el día 1 de enero ${ }^{49}$. En este alto cargo se mantuvo tan solo hasta el 25 de enero de 1855. En estos 24 días, expuso a la Cámara distintas leyes y otros proyectos que fueron aprobados, todos relacionados con la economía de la que tenía tantos conocimientos. Entre sus proyectos inacabados, que por su efímero paso por el Ministerio no se llevaron a efecto, estaba la Ley de Desamortización que la concluiría su sucesor en el cargo Pascual Madoz. No obstante, en los meses sucesivos, y por acusaciones de la oposición, tuvo que dar amplias explicaciones de algunas de sus actuaciones $^{50}$.

Sorprende ver que, a partir de la revolución de finales de junio en Vicálvaro y hasta el final del año 1854, la correspondencia entre estas dos personalidades tan solo contenía asuntos relacionados con la política. No obstante, en los primeros seis meses, sí hacía referencia a cuestiones financieras, aunque con muchos menos asuntos. Sevillano escribió sobre: la cuenta corriente de su cliente, con los movimientos por las entregas de efectivo a Canseco y el cobro de cupones; notas de Rothschild y Weissweiler (este último ofrecía la compra de una casa en París para cuando Narváez, decidiera trasladarse allí); cotizaciones de las obligaciones belgas, y de otros fondos, e incluso del grano; y las consabidas inversiones en letras sobre Granada.

\footnotetext{
${ }^{49}$ Se puede recordar que, en agosto de este mismo año, según le dijo Sevillano a Narváez, también le habían ofrecido este cargo de ministro de Hacienda, pero que él lo había rechazado por no existir un programa conveniente.

${ }^{50}$ En Cándida PÉREZ CLEMENTE (coord.), Ministros de Hacienda y de Economía. De 1700 a 2005. Tres siglos de Historia, Ministerio de Economía y Hacienda, Secretaría General Técnica, Madrid, 2005, pp. 208-209, se recogen los datos biográficos del duque de Sevillano.
} 


\section{AÑOS DE 1855 A 1859. CAMBIOS EN LA POLÍTICA}

Como se ha dicho, fue el 25 de enero de 1855, cuando el duque de Sevillano dimitió de su cargo de ministro de Hacienda. Pero antes de dar este paso, se puede ir viendo cómo se desenvolvía en su cargo, según se lo contó, día a día, a su general Narváez. Al ser tan descriptivas sus manifestaciones, se ha optado, en algunos casos, por incluirlas en su totalidad.

El primer día del año, Sevillano le escribió a Narváez diciéndole que el día 8 de diciembre había sido llamado por el Consejo de Ministros reunido en casa del presidente. Allí le manifestaron la necesidad indispensable de que aceptara el Ministerio de Hacienda dado el angustioso estado de fondos en que se encontraba el Tesoro. Sevillano seguía con que le habían dicho que podía emitir un empréstito de 40 millones hasta que se aprobasen las cuentas y que habían apelado a su patriotismo y sus sacrificios. Le explicó a su amigo distintos procedimientos y cobros de contribuciones, presupuestos del Estado y otros temas similares. Añadiendo que si le ofrecían el puesto era porque él era la persona idónea y porque gozaba de grandes simpatías en el Congreso. No obstante, Sevillano añadía que estas simpatías se acabarían cuando se rebajasen los presupuestos y en consecuencia el personal. Desde esta casa, continuó Sevillano, se fue a jurar ante la reina, y de allí, a las Cortes donde se leyó el Real Decreto. Terminó el largo escrito dándole a Narváez explicaciones de su actitud.

En los días sucesivos, el duque de Sevillano le contó a Narváez que la situación de Hacienda era mucho peor de lo que se esperaba, que estaba fatigado y que no encontraba momento para descansar. Le hacía mención de cómo la prensa de distinta ideología había recibido su nombramiento (decía que eran 60 los periódicos que salían a diario). Le comentó los problemas que tenía con los funcionarios que había cesado. Para acabar diciendo que, contra todo pronóstico, tras su nombramiento, la Bolsa había subido.

El día 15, le comentó que le escribía una nota, a la carrera:

«Que si en la cuestión económica se le pusiesen ostaculos por los Sres. Diputados, á los medios económicos que él proponía entonces se retiraría también por que él no quería substituirlos con los nuevos imaginarios que ellos en su sentir querían adoptar, mas no se retiraría por temor á la cuestion económica, sino por no dejársela desembolver en la línea que él proponía para poderla lleva adelante». 
Seguía comentando la situación del Tesoro, contribuciones, concesiones y demás. Diciendo que:

en la sesión de la comisión de presupuestos he tomado ya un gran terreno, para sino se accede á lo que apetezco, marcharme con honra el dia que me dé la gana (...) no sorprenderá que yo me vaya como un Ministro de un ramo especial, que ha de pagar sin tener medios, y estos no se le votan ${ }^{51}$.

En los días siguientes, continuó hablándole de su fatiga, de la mala situación encontrada, de la falta de recursos y que había obreros sin pagar. Repetía que iba arreglando cosas, y que él se iría cuando le diera la gana.

El día 23 de enero, Sevillano le confirmó a Narváez su dimisión, informándole que había comunicado al Consejo de Ministros que la Hacienda estaba mucho mejor que cuando él había llegado, ya que pronto entrarían millones por las contribuciones y otros conceptos. Después hacía este extenso detalle:

era preciso que el Consejo tuviese entendido que yo estaba resuelto á separarme por la cuestión política, por que veía al Gabinete próximo a recibir un voto de censura en el que yo no quería envolverme con el, porque la ultima votación que tanto le lisonjeaba, era para mi ficticia, tanto porque se marcharon cuarenta Diputados sin votar, como por que el Duque de la Victoria, no había hecho otra cosa que defenderse á sí propio, pero que no había dicho lo que yo hubiera dicho en su caso, á saber, que si el voto de censura se daba, el se retiraria también con sus colegas (...), de que aunque yo no participaba, me hicieron todos grandes esfuerzos para que no me fuese, pero les contesté, que mi resolución era irrevocable, fundándome para ella en la cuestión política unicamente, por que la económica no me arredraba. Me preguntaron si los bienes del clero debian, en mi opinión, unirse al proyecto de conversion de la deuda flotante, les dije que en mi opinion que eso debía ser sencillo (...) y que cuando estuviesen estos bienes en disposición de venderse se podrian ordenar. Lo mismo dije de los bienes de propios y que con todos se podria amortizar mucha deuda pública.

En los días siguiente, Sevillano continuó escribiendo sobre su dimisión, de la situación del nuevo ministro, de las interpelaciones en el Congreso, pero también de su salud. En otro momento le confirmó que «hice muy bien en aprovechar la ocasión que se me presentó, apoyada en la cuestión política, y largándome por ella». También le comentó lo que decían y callaban algunos periódicos en relación con su corto mandato, advirtiéndole a Narváez que no hiciera caso de lo que publicaban, que si él hubiera querido seguiría como ministro, ya que sabía que «pronto iba a tener pingües beneficios». En otro de sus escritos, Sevillano se quejó ante su amigo del poco tiempo

\footnotetext{
${ }^{51}$ Se ha conservado la ortografía y puntuación de estas notas «escritas a la carrera».
} 
que le dejaba su actividad en el Congreso para dedicarlo a sus negocios. Además, de que tenía que dar explicaciones de sus días de ministro.

El día 6 de agosto, después de escribirle sobre ciertas ideas y principios, le dijo que:

como jamás me he separado ni una sola linea de mis primitivos principios políticos, ni pienso separarme, espero impávido los sucesos, porque cualquiera que estos sean, mas ó menos, turbulentos, mas ó menos agitados, ó mas ó menos tranquilos, cada cual puede trabajar en obsequio de sus propias opiniones mucho, teniendo la oportunidad de aplicar sus actos para ello, á debida proporcional que las circunstancias lo requieran, pero que no haciendolo asi, sus servicios en obsequio de lo menor, no podrian continuar.

El día 30, Sevillano mostrando el mal momento con la política y sus dirigentes, añadió:

Este país es un establo, donde solo hay inmundicias, se necesitaba que pasase por el un gran rio para limpiarlas, pero no pasa ni aun un arroyo, mas claro, este pais necesita un Gobierno que gobierne, con esto solo basta y aun sobra, de lo demas nada hace falta.

En los siguientes escritos, Sevillano continuó dando noticias relacionadas con el devenir de los políticos y de los componentes del Gobierno español. De hecho, el 22 de marzo de 1856 legó a apuntar que: «este es el país de la intriga, la ambicion, la mentira, la ingratitud, en el la embidia devora a todos ó á la mayor parte».

Desde finales de enero de 1855, una vez superado el asunto del Ministerio de Hacienda, Sevillano volvió a hacer comentarios relacionados con su vida profesional, dándole a Narváez referencias de cotizaciones y suscripciones de fondos en París y Londres. Asimismo, escribiéndole con detalles de su cuenta corriente. Le advirtió, en repetidas ocasiones, que no se pagaba ni un solo cupón por la mala situación de la Hacienda, y seguido criticó la actuación de Madoz, el nuevo ministro, "que lo hace cada vez peorn. En otro momento, le escribió sobre la compra de caballos y temas relacionados con esta. También sobre inversiones en sociedades extranjeras como «Credit Moviliare ${ }^{52}$, ferrocarriles o la Deuda Flotante española.

En el aspecto familiar, el 29 de marzo, comunicó que su alegría de que hubiera salido bien de su operación, pero a la vez le dio la noticia de que había fallecido el

\footnotetext{
${ }^{52}$ El Crédit Mobilier fue un banco francés creado en 1852 y que desapareció en 1867.
} 
conde de la Vega del Pozo, lo que le había afectado mucho. Más adelante, le siguió preguntado por la mala salud del general y aplaudía su decisión de ir a tomar las aguas de Vichy (que, por cierto, le produjeron irritaciones de las que se recuperó en Orleans $)^{53}$. Aprovechó la ocasión para aconsejarle que no viniera a Madrid, ni a Loja ni a Sevilla y para decirle que, según publicaba la Gaceta, él era ajeno de todo lo que pasaba en España, aunque algunos, continuaba Sevillano, lo achacaran a un capricho que le hacía parecer un proscrito. Asimismo, confirmó su mutua simpatía y amistad, que «tan solo la Parca podría acabar».

El 14 de agosto, Sevillano, como portavoz de otros componentes de la Junta, pidió ayuda económica a Narváez para las enfermedades de los menesterosos de la Corte. El general, según se ha visto por otras cartas del banquero, le debió contestar con agradecimiento y poniendo a su disposición 1.000.- reales de vellón.

Durante los primeros meses de 1856, eran constantes las cartas que Sevillano le hablaba a Narváez sobre su viaje a Loja, aplazado constantemente, aunque el mismo O'Donnell le había asegurado que el general podría ir a su pueblo cuando quisiera, que nunca se le había prohibido. Sin embargo, el duque de Valencia continuó en distintos puntos de Francia y, según decía Sevillano, estaba deseoso de abrazar con calor a su amigo, que prometió ir a visitarle, aunque fuera un problema el desconocimiento del idioma, pero que no podía pasar más tiempo sin abrazarle.

Así continuaron yendo y viniendo las cartas, con noticias de España y órdenes desde Francia que Sevillano se aprestaba a cumplir. Aunque en ningún momento detallaba cuales eran estas, pero en especial, escribiendo acerca del anunciado viaje de Narváez a España, a Madrid, y a Loja, que tantas veces se había visto interrumpido, aunque Sevillano le aseguró que en su llegada no recibiría animadversión de nadie.

Aunque no se ha visto que se lo dijera en ninguna de las cartas conservadas, el 2 de septiembre de 1856, el duque de Sevillano dejó su asiento de diputado.

Y precisamente, el 12 de octubre de 1856, Narváez volvió a tomar el mando de la Presidencia del Consejo de Ministros, supliendo a Leopoldo O'Donnell. Se mantuvo en el cargo justo un año y 3 días, ya que el 15 de octubre del año siguiente abandonó el puesto, sucediéndole Francisco Armero. Es preciso señalar que, cuando el duque de Valencia ocupaba esta Presidencia, no residía en el palacio de Sevillano, así como que

\footnotetext{
${ }^{53}$ Manuel SALCEDO OLID: Ramón María Narváez..., op. cit., p. 521.
} 
la correspondencia entre los dos personajes era prácticamente inexistente. De hecho, durante este año tan solo se han localizado dos escritos, del 3 de abril y del 3 de agosto, en los que Sevillano le hacía mención sobre alguna presentación de políticos afines al general moderado, en aquel momento en la Presidencia.

En febrero de 1857, en las elecciones municipales, el duque de Sevillano fue elegido concejal del Ayuntamiento de Madrid.

En junio de 1858, Sevillano, además de alegrarse de que estuviera bien, le comentó a su amigo temas relacionados con sus mutuos negocios; sobre unas minas carboníferas y el negocio de estas, así como escrituras y fundadores de esta por lo que Narváez se había interesado. Unos meses más adelante, Sevillano citó temas relacionados con las acciones de los caminos de hierro y sobre "Credit Moviliare». A la vez, ante posibles recomendaciones que le pedía Narváez, Sevillano le contestó que no tenía ninguna relación ni influencia con el actual Gobierno.

\section{AÑOS DE 1860 A 1866. EL INICIO DEL FINAL}

En su carta del primero de enero del 1860, Sevillano haciendo referencia al obsequio le que había enviado al duque Valencia, aunque sin decir qué era el regalo, como de costumbre, aprovechó la ocasión para mostrarse agradecido por otros presentes que el militar le había hecho, a la vez que reconocía la amistad que le brindaba Narváez.

En febrero, abril y septiembre, además de incluir en sus escritos anónimos de distinta índole, Sevillano aprovechaba sus cartas para hacer una exaltación de la amistad existente entre los dos amigos, «ininterrumpida durante largos años

", añadiendo lo mucho que lo apreciaba. Asimismo, le insistía sobre su viaje a Loja, donde, aseguraba el banquero, el general estaría más a su gusto, aunque, consideraba que debería pedir permiso, porque su llegaba «levantaría tormentas apoyadas en chismes inventados»

El 24 de febrero de 1862, Sevillano volvió a escribir a Narváez acerca de su viaje a Aranjuez y de sus deseos de que todo fuera bien. El 17 de octubre, la carta de este día nuevamente tenía comentarios sobre regalos de uno a otro. En esta ocasión, era el banquero quien agradecía al general su envío de una remesa de bastantes botellas de vino, del que le gustaba a él. Sevillano le contestó, en una misiva con una 
«S» en relieve coronada, anunciando que le enviaba un pequeño recuerdo, y añadiendo que recordaba con afecto la amistad que existía entre ellos, y que les hacía tener una perpetua confianza.

Desde primero de abril y hasta noviembre de 1862, el duque de Sevillano le escribió múltiples cartas al de Valencia, que estaba en su natal Loja, sobre varios temas, como fue la contratación de un sirviente o un cocinero, ante la visita que le iba a realizar la reina en su casa, recepción para la que tuvo pedir un total de 400.000.reales a su banquero ${ }^{54}$. Pero en especial, estos escritos estaban centrados en la parte económica que unía a los dos protagonistas. Era, entre otras cosas, acerca de letras sobre Granada y Málaga (siempre su tierra natal o provincias colindantes), tipos de interés y de cambio, pago de cupones y otras cuestiones relacionadas con los movimientos por entregas en efectos o en efectivo a Canseco, desde la cuenta del militar con el banquero. El 6 de noviembre, Sevillano le remitió a su cliente un extracto de la cuenta corriente con un saldo a favor del banquero de 600.062,02 reales. Este escrito contiene unas anotaciones de Narváez con su conformidad a los movimientos y con las instrucciones a su apoderado para que le entregara el importe a su favor. A los pocos días, el propio Sevillano le comunicó a Narváez que había recibido de Canseco el citado saldo. De hecho, se puede recordar que como una prueba de que Narváez llevaba un control de sus cuentas con el banquero, uno de los expedientes que conservan estos escritos está titulado: Año 1862. Correspondencia con el Sr. Duque de Sevillano en la que constan las cantidades que me adelanto en dicho año y el pago que de todas ellas le hice resultando no deberle nada el día 15 de enero de 1863.

El 10 de septiembre de 1863, era Vicente Díez Carmona quien se dirigió al duque de Valencia anunciándole que el duque de Sevillano le había entregado endosadas a su nombre cuatro letras de cambio sobre Granada por un total de $63.602,50$ reales, y que él se las remitía endosadas a su nombre ${ }^{55}$. Al día siguiente, Sevillano, ahora la carta con un tipo de letra diferente y mucho más clara (se entiende que de algún empleado del banquero), escribió a su amigo en Loja para continuar hablándole de algunas letras sobre Granada.

\footnotetext{
${ }^{54}$ Manuel SALCEDO OLID: Ramón María Narváez..., op. cit., pp. 651-652.

${ }^{55}$ Es destacable que el general Narváez, como se viene reflejando en todo el trabajo, tuviera habitualmente en su cartera efectos sobre Granada, en definitiva, sobre su tierra.
} 
El 12 de enero de 1864, el banquero, con una salud delicada, informó a Narváez remitiéndole un extracto de su cuenta al 31 de diciembre del año anterior. En este caso, constaba que el saldo a favor del banquero ascendía a 259.119,50 reales, incluyendo un detalle de las partidas al Debe y al Haber que justificaban los movimientos en todo el año, como el cobro de cupones, los pagos por cuenta del militar y otros conceptos. A los tres días, Sevillano escribió hablándole de la amortización de 20 obligaciones de ferrocarriles, y que del cobro se encargaría el banquero abonando su importe en la cuenta de Narváez, rebajando, lógicamente, su saldo. El día 20 de este mismo mes, Sevillano le apuntó a Narváez que había abonado en su cuenta 120.000.- reales, por el cupón vencido que había cobrado en eses mes, sobre su depósito de cuatro millones. A la vez, hizo referencia sobre 2.000 obligaciones del Estado y sobre subvenciones de ferrocarriles, que eran propiedad de Narváez pero que Sevillano, como su banquero, tenía en su poder.

Ya hacía tiempo que el duque de Sevillano había abandonado tanto la vida política como financiera y social. Así fue que, después de haber permanecido unos días enfermo, el 15 de febrero de 1864, falleció Juan de Mata Sevillano y Fraile, el I duque de Sevillano y I marqués de Fuentes de Duero, con Grandezas de España ${ }^{56}$. El conde de Goyeneche, marido de su hija María Nicolasa, y testamentario del fallecido noble, fue el encargado de dar la noticia a S. M. la reina y al presidente del Senado, institución a la que, ininterrumpidamente, había pertenecido el finado desde diciembre de 1846.

No obstante, debían continuar en vigor las cuentas entre los dos nobles, ya que el 31 de marzo, la condesa viuda de la Vega del Pozo y la condesa de Goyeneche, hijas y herederas del fallecido duque de Sevillano, se dirigieron a Narváez diciéndole que habían recibido de este la cantidad de 99.119,50 reales, como el importe del saldo que debía existir en la cuenta corriente hasta esa fecha a favor del banquero. Esta cantidad quedó incrementada en la testamentaría del duque vicalvareño. Este importe se entiende que era el saldo de la cuenta al 31 de diciembre de 1863, menos la entrega de 120.000.- reales y el vencimiento de las obligaciones de los ferrocarriles, que debían ser por 40.000.- reales.

\footnotetext{
${ }^{56}$ Agustín FERNÁNDEZ ESCUDERO: El negocio de la política..., op. cit., pp. 133-138, incluye datos del testamento, memoria y codicilo bajo de este noble, con detalles de algunas de sus cláusulas, herederos e instrucciones para el descanso de su cuerpo y de su alma.
} 
De todas formas, es preciso destacar que, sí se ha visto la liquidación de la cuenta, pero en ningún momento se ha visto cómo y a quien se hizo la entrega de los títulos y demás efectos que, como se viene indicando, mantenía en banquero por cuenta del duque de Valencia.

El 16 de septiembre, Narváez ocupó el cargo de la presidencia, por penúltima vez, también de forma efímera, ya que tan solo se mantuvo hasta el 21 de junio del año siguiente que nuevamente le sucedió Leopoldo O'Donnell.

Pero a pesar de la muerte del banquero vicalvareño, parecía ser que las relaciones comerciales entre sus herederas y el duque de Valencia estaban presentes, aunque sin quedar claro que las hijas del duque de Sevillano continuaron siendo las banqueras de Narváez, ahora que este era el presidente del Gobierno. Hecho que resultaría como mínimo paradójico. Hay un recibo del 27 de noviembre de 1865, por el que el duque de Valencia decía haber recibido de las señoras duquesas de Sevillano y marquesa de Fuentes de Duero la cantidad de 30.000.-reales de vellón que le habían adelantado "y cuya suma devolveré á su voluntad». El 18 de diciembre, otro recibo, ahora de 60.000.- reales, con la misma clausula. El 18 de enero de 1866, hay una nota firmada por Canseco en la que decía haber entregado a las citadas herederas los 90.000.- reales que le habían entregado a Narváez.

\section{CONCLUSIÓN}

Una vez repasado el contenido de estas múltiples cartas que Juan de Mata Sevillano le dirigió a su cliente, amigo, general y principal componente de su partido moderado, se puede asegurar que en el mismo, como se ha anticipado, se mezclaban los tres asuntos que a los dos personajes les interesaban: la situación financiera propia del general, de España y del resto de Europa; los pormenores de sus vidas domésticas, con las idas y venidas del general a España y a Loja, después de sus exilios; y como no, la puesta en escena del Partido Moderado en distintos momentos de la Historia de España, con el general Narváez al frente de la nación y el duque de Sevillano a su disposición.

Como se ha visto, es preciso formularse algunas preguntas, aunque, de momento, no se tengan las respuestas. Por ejemplo, sobre el destino de los títulos que, a nombre del general Narváez, tenía la casa Sevillano. Asimismo, hay que 
apuntar que se desconoce la procedencia exacta de los fondos que, de un lado a otro, movía e invertía Sevillano por cuenta de su cliente el general Narváez, así como si este, además de trabajar con este banquero, lo hacía con algún otro en Madrid. Y, por último, si este militar y su apoderado tenían una contabilidad que controlara el movimiento y situación de sus finanzas.

También, cómo, Sevillano, a pesar de su ambigüedad política, con el transcurrir de sus escritos y los contactos con su cliente, se fue mostrando, en apariencia, cada vez más moderado, llegando a ser senador, diputado y ministro, aunque, por otro lado, había financiado la revolución progresista de 1854 y que fue a recibir a los dos generales, O'Donnell y Espartero, antes de que estos se dieran su abrazo en Madrid. Sin embargo, obligatorio es recordar que sus primeros títulos los logró gracias a sus contactos con la Casa Real y sus servicios económicos y políticos a España y a la reina, en uno de los momentos más difíciles de su reinado, y por sus deseos de ascender peldaños en la escala social y que, tanto él como sus dos hijas, estuvieran cada vez más introducidos en la nobleza.

\section{BIBLIOGRAFÍA}

BARTOLOMÉ MARCOS, Luis et al: Historia de Vicálvaro, Ayuntamiento de Madrid, Madrid, 1987.

CALLEJA LEAL, Guillermo C., "Las revoluciones de 1854 y 1856 en Madrid», en Revista Historia Militar, núm. 87, año 1999, pp. 11-62.

CÁNOVAS SÁNCHEZ, Francisco: «Los partidos políticos» en La era isabelina y el sexenio democrático, tomo XXXIV de la Historia de España de Menéndez Pidal, Espasa Calpe, Madrid, 1981.

CORRAL, José del: «El duque de Sevillano y el marqués de Linares. Dos financieros madrileños del XIX», en José del Corral et al, Personas y personajes de la vida madrileña: su época y su historia, Cámara Comercio e Industria, Madrid, 1991.

CRUZ, Jesús: Los Notables de Madrid. Las bases sociales de la revolución liberal española, Alianza Editorial, Madrid, 2000.

FERNÁNDEZ ESCUDERO, Agustín: El Negocio de la Política. Biografía del duque de Sevillano (Vicálvaro 1790-Madrid 1864), La Ergástula, Madrid, 2013. 
HERCE MONTIEL, Pablo: La Duquesa de Sevillano y su obra social, Institución Provincial de Cultura Marqués de Santillana, Excelentísima Diputación Provincial y Excelentísimo Ayuntamiento de Guadalajara, Guadalajara, 1999.

KIERNAN, Victor Gordon: The revolution of 1854 in Spanish History, Oxford at the Clarendon Press, Oxford, 1966.

LÓPEZ JIMÉNEZ, José Enrique, «Españoles en la Guerra de Crimea», Ejército de Tierra Español, núm. 834, octubre 2010, pp. 104-109.

MÁRQUEZ DE LA PLATA, Vicenta María y VALERIO DE BERNABÉ, Luis: El libro de otro de los duques, Prensa y Ediciones Iberoamericanas, Madrid, 1994.

MERINO MERCHÁN, José Fernando y MATEOS DE CABO, Óscar Ignacio: La "Vicalvarada": 140 años después. Aproximación al significado jurídicoconstitucional del Bienio Progresista (1854-1856), Congreso de los Diputados, Madrid, 1994.

PABÓN Y SUÁREZ DE URBINA, Jesús: Narváez y su época, Espasa-Calpe, Madrid, 1983.

PÉREZ CLEMENTE, Cándida (coord.), Ministros de Hacienda y de Economía. De 1700 a 2005. Tres siglos de Historia, Ministerio de Economía y Hacienda, Secretaría General Técnica, Madrid, 2005.

SALCEDO OLID, Manuel: Ramón María Narváez (1799-1868), Homo Legens, 2012.

TOMÁS VILLARROYA, Joaquín: «El proceso constitucional», en La era isabelina y el sexenio democrático, tomo XXXIV de la Historia de España Menéndez Pidal, Espasa-Calpe, Madrid, 1981.

URQUIJO Y GOITIA, José Ramón: La Revolución de 1854 en Madrid, Instituto de Historia Jerónimo Zurita, Madrid, 1984.

\section{HEMEROTECA}

El Áncora

La Carta

El Católico

El Clamor Público

Diario Oficial de Avisos de Madrid

La Época

La España

La Esperanza

Gaceta de Madrid 
El Heraldo

El Heraldo de Madrid

La Iberia

\section{ARCHIVOS}

Archivo General del Ministerio de Justicia

Archivo Histórico Nacional

Archivo Palacio Real

Archivo de Villa de Madrid

Asociación de Investigación Histórica de Vicálvaro. Vicus Albus

Real Academia de la Historia 